\begin{tabular}{|c|c|c||}
\hline Received: June 2019 & Accepted: August 2019 & Published: October 2019 \\
\hline \hline \multicolumn{2}{|l|}{ Article DOI: http://dx.doi.org/10.24903/sj.v4i2.309 } \\
\hline
\end{tabular}

\title{
Theoretic Analysis of Implicatures in Pride and Prejudice and Its Pedagogical Implications
}

\author{
Dita Rizki Anggraini \\ Sriwijaya University \\ anggrainidita2384@gmail.com \\ Ismail Petrus \\ Sriwijaya University \\ ismailpetrus@yahoo.com \\ Rita Inderawati \\ Sriwijaya University \\ ritarudisaid@yahoo.com
}

\begin{abstract}
This study was aimed at finding out the implicatures, the types of the implicatures, and the intended meaning of the implicatures employed by the characters in Jane Austen's Pride and Prejudice. This study was a descriptive qualitative study with a corpus-based approach. The data were collected through some procedures, namely reading the novel repeatedly and thoroughly, determining the utterances containing implicatures in dialogues based on the relevance theory, and selecting and organizing the data to be analyzed. To analyze the data, the procedures were presenting and describing the data, interpreting the data by referring to the relevance theory, determining the implicated premises and implicated conclusions, determining the strongly implicated conclusions and weakly implicated conclusions, and interpreting and describing the intended meanings of the implicatures. From the results, there were 60 implicatures found in the novel and the two types of them were strong and weak implicatures. As the follow-up, dissemination to the second-semester students of Graduate Program of Sriwijaya University was conducted which yielded to the result that there was no significant association between the respondents' knowledge of implicatures and relevance theory and their performance in analyzing implicatures using the theory with the $p$-value of 0.406 ( $p$-value $>0.05)$.
\end{abstract}

Keywords: implicatures; relevance theory; knowledge; performance 


\section{INTRODUCTION}

In communication, the speaker's utterances interpretation should be recognized by the hearer as intended. (Grice, 1975; Chemezov \& Gural, 2015; Mazzone, 2013; Mitchell, Robinson, \& Thompson, 1999) proposes a set of principles be employed called cooperative principles which include four sub-principles or maxims to be observed. Those four maxims are the maxim of quality, quantity, relation, and manner. Nevertheless, in some circumstances, people might flout the maxim while reckoning their hearer to understand what they say (Paltridge, 2012; Kleinke, 2010; Vergis, 2017). This kind of action, later on, will produce a phenomenon called implicature. Thomas (1995) shows examples of implicature as follow,

(1) 'We must remember your telephone bill', she said hinting that Louise had talked long enough. 'Goodbye', said Louisa, ringing off.

(2) Late on Christmas Eve 1993, an ambulance is sent to pick up a man who has collapsed in Newcastle city center. The man is drunk and vomits all over the ambulance man who goes to help him. The ambulance man says:

'Great, that's really great! That's made my Christmas!'

The speakers in both examples (1) and example (2) implicitly convey their intention beyond the words they are saying. For example (1), Louisa had an intention to end the telephone conversation by reminding Louise about the telephone bills while for example (2) it is clear that the ambulance man tried to convey the opposite meaning from his utterance - that his Christmas was totally awful.

Relevance theory, suggested by (Sperber \& Wilson, 1986; Guerrero, 2016; Syrett et al., 2017) can be one of the principles or bases in interpreting implicatures. Instead of four, like in Grice's theory of co-operative principles, relevance theory bases its interpretation on a single principle of relevance. In this theory, cognitive and communication are the aspects being considered in order to get the meaning implied in the utterances.

Pride and Prejudice, a classic regency novel was written by Jane Austen, is one of the novels which contain implicature and have moral values that correspond to both global and Indonesian government expectations. Ispriyani (2008) categorizes the moral values from Austen's Pride and Prejudice into some categories; two of them are social relationships and friendship. It can be simplified that, at least, being resilient, tolerant or respectful and interactive to others are the moral values learned from this novel. Those moral values are in accordance with the report of (Nunan, 2003; Tan, Mahadir Naidu, \& Jamil@Osman, 2018; 
Thornberg \& Oğuz, 2016) that resilience, respect or tolerance, and interaction are expected to be possessed in $21^{\text {st }}$-century learning.

Implicature itself, according to (Grundy, 2008; (Dinges, 2015; Holtgraves \& Kraus, 2018), enables us to interpret what is being said by utilizing context. Additionally, this interpretation requires critical thinking skills. As one of the global demand, critical thinking is expected to be involved in $21^{\text {st }}$-century learning. Scott (2015) states that there are four aspects that represent the $21^{\text {st }}$-century kind of learning, namely critical thinking and problem-solving, communication, collaboration, as well as creativity and innovation (4C). Moreover, implicature is also related to the next aspect of $4 \mathrm{C}$ which is communication as it does occur in the communication, either orally or spoken.

The concept of $4 \mathrm{C}$ is also formulated in the Industrial Revolution 4.0 or also known as Cyber-Physical System. The educational sector, especially in Indonesia, considers that $4 \mathrm{C}$ is the formula to struggle in the Industrial Revolution 4.0 era which bases on the concept of IoT (internet of things). Ali Ghufron Mukti, general director of science and technology resources and directorate of higher education believes that through the concept of $4 \mathrm{C}$, Indonesian colleges will survive in the era of Industrial Revolution 4.0. (Ditjen Sumber Daya Iptek Dikti, 2018).

Likewise, the Indonesian government looks forward to shaping the generation who are compatible to face the global competition. Consequently, critical thinking is integrated with today's curriculum, both the 2013 Curriculum (Depdikbud, 2013) for primary and secondary schools and the Indonesian Qualifications Framework or IQF-based Curriculum (Indonesia, 2012) for tertiary schools.

In fact, implicature is still considered as an obstacle for the students in comprehending texts. (Sartini, 2014; Dinges, 2015; Holtgraves \& Kraus, 2018) found out that students still faced difficulties in analyzing one of the two types of implicatures being observed, particularized implicature. In addition, Indonesia is placed on the $62^{\text {nd }}$ place out of 70 countries which are still categorized as low (OECD, 2016). From this fact, since PISA administered the test which integrates critical or higher-order thinking skills, then it also represents the Indonesian students' low critical thinking skills.

The objectives of this study were to find out the implicatures, the types of implicatures, and the intended meanings of the implicatures employed by the characters in Jane Austen's Pride and Prejudice. 


\section{METHODOLOGY}

In conducting the study, the descriptive method with a corpus-based approach was used. In this case, one of the language phenomena, implicature, provided in a novel entitled Pride and Prejudice, was analyzed and categorized into two types of implicatures. The analysis was based on Sperber \& Wilson's (1986) theory of relevance. Besides, this study was also aimed to figure out the intended meaning beyond the utterances uttered by the characters of the novel.

The object of this study was Pride and Prejudice novel originally written by Jane Austen in 1813. This novel consists of 60 chapters and 273 pages. The utterances in dialogues containing implicatures were taken as the data. In this study, Austen's Pride and Prejudice were chosen as the object due to several reasons. The main reasons were because a lot of implicatures were found in this novel after being read several times. The other reasons are due to its good reputation, its author's reputation, and its moral values.

In collecting the data, the novel was repeatedly read to determine utterances containing implicatures. In this study, all the utterances containing implicatures in dialogues in Pride and Prejudice novel were taken as the data. Specifically, their procedures done in collecting the data were reading the novel from the first until the last chapter thoroughly, determining the utterances containing implicatures in dialogues based on RT, and selecting and organizing the data to be analyzed.

Then, the data analyzed using the descriptive method by considering the theory of relevance. The procedures were presenting and describing the data, interpreting the data by referring to RT, determining the implicated premises and implicated conclusions, determining the strongly implicated conclusions and weakly implicated conclusions, and interpreting and describing the intended meanings of the implicatures.

As the further action of this study, a booklet was made and a dissemination program was conducted. The booklet consisted of 26 pages which included the description of implicatures, the explanation about RT, and the description of how to analyze the implicatures referring to RT with its example taken from the Jane Austen's Pride and Prejudice.

The dissemination was administered to the second-semester students of the Graduate Program of Universitas Sriwijaya majoring in English Education Study Program who had taken the Pragmatics course. They were given a questionnaire and then exercises after being exposed to the implicature and relevance theory. Then the data obtained were analyzed using the Chisquare Association Test to know whether there was a significant association or not as hypothesized. 


\section{FINDINGS AND DISCUSSION}

\section{Findings}

Based on the data analysis, there were 60 implicatures found in the dialogues among the characters. The following are some of the implicatures existed in the dialogues employed by the characters in Jane Austen's Pride and Prejudice.

Datum 01/CH-01/P-01

\section{Context}

Mrs. Bennet excitedly told her husband that Netherfield Park was taken by a single wealthy man, Mr. Bingley. As a response, Mr. Bennet asked whether the man was married or not.

\section{Dialogues Containing Implicatures}

Mr. Bennet: What is his name?

Mrs. Bennet: Bingley.

Mr. Bennet: Is he married or single?

Mrs. Bennet: Oh! Single, my dear, to be sure! A single man of large fortune; four or five thousand a year. What a fine thing for our girls!

Mrs. Bennet implied something in her utterance as she did not directly say what was in her mind. Without inferring that Mrs. Bennet wanted Mr. Bingley to marry one of her daughters or Mr. Bingley was an ideal son in law to be, it would be difficult for Mr. Bennet to get the optimum relevance of his wife utterance. Therefore, the conclusions below are the most accessible by considering the context. Besides, they can also be justified by the assumption about the world that surely every mother wants her daughter to live happily by marrying her to a wealthy man.

\section{Implicated Premises}

That Mr. Bingley was a wealthy man was very advantageous.

Strongly Implicated Conclusion

Mrs. Bennet wanted Mr. Bingley to marry one of her daughters.

Weakly Implicated Conclusion

Mr. Bingley was an ideal son in law to be. 


\section{Intended Meaning}

Knowing that Mr. Bingley was the unmarried owner of Netherfield Park, it is clear that Mrs. Bennet implied planning to marry one of her daughters to Mr. Bingley. He was also very ideal to be a son in law as he had a lot of fortune.

Datum 04/CH-01/P-02

\section{Context}

Mrs. Bennet was annoyed since her husband was abusing their daughters and claimed that Mr. Bennet had no concern about her feeling.

\section{Dialogue Containing Implicature}

Mrs. Bennet: Mr. Bennet, how can you abuse your own children in such a way? You take delight in vexing me. You have no compassion for my poor nerves.

Mr. Bennet: You mistake me, my dear. I have high respect for your nerves. They are my old friends. I have heard you mention them with consideration these last twenty years at least.

\section{Data Description}

Mr. Bennet obviously implied something in his utterance. The conclusions below are accessible in terms of both communicative and cognitive principles. By inferring the conclusions, Mrs. Bennet's expectation could be satisfied based on the context that her husband was actually patient enough for having listened to the same thing for the last 20 years; he was a good husband instead. Moreover, they are even more relevant by relating and justifying them to the existing assumption that, in general, most of a good or patient husband will patiently accept whatever his wife complained about and try to grant whatever she wants. Hence, by considering the context and existing assumption, the most accessible and relevant conclusion of that implicature are the conclusions below.

\section{Implicated Premise}

Mrs. Bennet had done the same thing frequently.

\section{Strongly Implicated Conclusion}

Mr. Bennet was patient enough dealing with his wife.

Weakly Implicated Conclusion

Mrs. Bennet was a good husband. 


\section{Intended Meaning}

After listening to his wife's complaints, Mr. Bennet was trying to defend himself by realizing Mrs. Bennet that he was actually that patient. He had been dealing with the same thing for the last 20 years which showed his true concern on Mrs. Bennet's feelings. He was a good husband indeed.

\section{Discussion}

Based on the results of the study, there were some aspects that can be discussed. First, it showed that, in writing their works, most of the authors or novelists are likely to use implicature for several goals, which are to make the conversation livelier and more interesting, to show politeness, and to express sarcasm. In line with their study, Nanda, Sukyadi, and Ihrom (2012) found that one of the goals of employing implicature was to optimize a polite reprimand.

Table 1. Examples of Implicature based on Its Goal found in Pride and Prejudice Novel

\begin{tabular}{|c|c|}
\hline Goals & Example (in Pride and Prejudice) \\
\hline $\begin{array}{l}\text { To make the } \\
\text { conversation } \\
\text { livelier and more } \\
\text { interesting }\end{array}$ & $\begin{array}{l}\text { Datum } 01 / \mathrm{CH}-01 / \mathrm{P}-01 \\
\text { Mr. Bennet: What is his name? } \\
\text { Mrs. Bennet: Bingley. } \\
\text { Mr. Bennet: Is he married or single? } \\
\text { Mrs. Bennet: Oh! Single, my dear, to be sure! A single man of large } \\
\quad \text { fortune; four or five thousand a year. What a fine thing for } \\
\quad \text { our girls! }\end{array}$ \\
\hline To show politeness & $\begin{array}{l}\text { Datum 37/CH-20/P-79 } \\
\text { Mrs. Bennet: What do you mean, Mr. Bennet, in talking this way? You } \\
\text { promised me to insist upon her marrying him. } \\
\text { Mr. Bennet: My dear. I have two small favors to request. First, that you } \\
\text { will allow me the free use of my understanding on the } \\
\text { present occasion; and secondly, of my room. I shall be } \\
\text { glad to have the library to myself as soon as may be. }\end{array}$ \\
\hline $\begin{array}{l}\text { To express } \\
\text { sarcasm }\end{array}$ & $\begin{array}{l}\text { Datum 09/CH-03/P-07 } \\
\text { Mr. Bingley: Come, Darcy. I have to make you dance. I hate see you } \\
\text { standing about by yourself in this stupid manner. You had } \\
\text { much better dance. } \\
\text { Mr. Darcy: I certainly shall not. You know how I detest it, unless I am } \\
\text { particularly acquainted with my partner. At such an } \\
\text { assembly as this it would be insupportable. Your sisters } \\
\text { are engaged, and there is not another woman in the room } \\
\text { whom it would not be a punishment to me to stand up with. }\end{array}$ \\
\hline
\end{tabular}

For the first example, it is clear that Mrs. Bennet implied her second utterance as she gave new information that was actually not asked. By relating it to the context, it is very accessible to assume that Mrs. Bennet implied that she wanted one of her daughters to marry Mr. Bingley. Mrs. Bennet's giving new information in this conversation triggered Mr. Bennet 
to give another response. This is supported by the finding found by Ngenget (2017)) of implicatures employed by Manado Malay language speakers that they generally did it for the goal of giving information. For the second example, from Mr. Bennet's utterance, it is clear that he did not directly state what he wanted. In fact, Mr. Bennet wanted his wife to go away and let him alone; however, he did not directly drive his wife away. This obviously showed that Mr. Bennet chose phrases that were more polite though it actually contained negative meaning. For the last example, Mr. Darcy gave extra information that was not actually expected. In his utterance, instead of directly saying that there were no women attractive enough so that he would not dance, Mr. Darcy used satire to show it by saying the italicized utterance. He used the word 'punishment' to represent the phrase 'unattractive women'.

After that, it can be inferred that people's language use is influenced by various factors; they are culture, social class, gender, age, even ethnicity. The country like the United Kingdom has similarities to Asian countries as both people are indirect communicators and tend to use diplomatic language for the reason of politeness (Evason, 2019). They prefer to say unpleasant things into more appropriate and positive phrases. Subsequently, Trudgill (2000) shows that social status, gender, and ethnicity influence language forms and variation. It is found that upper-middle-class speakers almost always use the standard variant, while the lower-middleclass speakers use the non-standard one. In addition, Arbain \& Sandi (2016) also proved the influence of ethnicity on language use. It was found that casual languages like African American Vernacular English (AAVE) and American slang were applied in the song lyrics of Eminem, who was side of blacks American.

Furthermore, in terms of age, explains that adolescents commonly use more non-standard varieties than younger adults; from adolescence to adulthood, younger adults tend to use more standard forms of speech until a particular stage (Holmes, 2007). For the gender aspect, men and women are different in terms of directness. Tannen (1990) also points out that women use more indirect speech, whereas men use less indirect speech.

\section{Pedagogical Implication}

In this $21^{\text {st }}$ century era, learning about implicatures is essential for the students as it allows them to think critically. This fact is tightly relevant to what the world expects of the outcomes of this era. They have to be critical, creative, communicative, and collaborative which is formulated as $4 \mathrm{C}$. These criteria of $21^{\text {st- }}$ century learning are proposed and supported by various global educational organizations such as UNESCO and P21. 
For the teachers, providing teaching and learning materials which contain implicatures, like the novel, can stimulate the students to think critically that is able to foster their critical thinking skills. Curricula, syllabi, and lesson plans integrating critical thinking are strongly believed to be beneficial in this kind of case. It is also harmonious with Indonesian curricula, both for the 2013 Curriculum and IQF-based Curriculum which are aimed to create critical outcomes. It means that providing materials with implicature can help the government to produce the expected young generation for our country.

Since implicatures deal with the students' pragmatic competence, as one of the components of language, it might influence the students' language proficiency. This is in line with the study conducted by Abdelhafez (2016) which shows that the students' pragmatic competence is positively significantly correlated to their language proficiency at the level of 0.730. It implied that students with good pragmatic competence have better proficiency.

Next, as the students have to read the story first, it will absolutely influence their lexical resources or vocabulary achievement which are beneficial to their language proficiency. This is really urgent for our country since EF EPI (2017) globally ranks Indonesia in the $51^{\text {st }}$ place out of 88 countries in 2018. The score of Indonesia is 51,58 which is categorized as low proficiency. The study from (Rachman, Nur, Sunarti, \& Puspita, 2019) also depicted the similar fact that they found the low vocabulary and English skills of Indonesian students becomes two of the obstacles of teachers in generating target language (English) in teaching and learning process.

Finally, the use of the novel might be very beneficial for students' intercultural competence, sociolinguistic competence, and interpersonal skill. By analyzing a language feature in a literary text, the students need to relate how culture, social status, and other aspects influencing someone's language use and to understand how to have an interaction or communication with others. These competencies and skills, indeed, are expected to be possessed by the students of $21^{\text {st- }}$ century learning.

Dissemination Results

The results of the dissemination were divided into two, based on the knowledge and based on the performance. Then, the respondents were categorized into three categories, i.e. poor, moderate, and good. The following table represents the percentage of students belonging to each category.

Table 2. The Dissemination Results 


\begin{tabular}{lccc}
\hline & Poor & Moderate & Good \\
\hline $\begin{array}{l}\text { Students' Background Knowledge about Implicature and } \\
\text { Relevance Theory }\end{array}$ & $42 \%$ & $33 \%$ & $25 \%$ \\
\hline $\begin{array}{l}\text { Students' Performance in Analyzing Implicature Using } \\
\text { Relevance Theory }\end{array}$ & $17 \%$ & $42.5 \%$ & $42.5 \%$ \\
\hline
\end{tabular}

It can be concluded that most of the respondents fairly succeed to analyze implicature appropriately, which represented their critical thinking. However, the was a discrepancy in the percentage between the knowledge and the performance. This showed that respondents were categorized differently both in their knowledge and performance. This fact might lead to the assumption of whether the two variables, knowledge and performance, have a significant association or not. Hence, the Chi-Square Association Test was conducted.

Table 3. Chi-Square Association Test Results

\begin{tabular}{lccc}
\hline \multicolumn{3}{c}{ Chi-Square Tests } & \\
\hline & Value & Df & Asymp. Sig. (2-sided) \\
\hline Pearson Chi-Square & $4.000^{\mathrm{a}}$ & 4 & .406 \\
Likelihood Ratio & 4.763 & 4 & .312 \\
Linear-by-Linear Association & 2.812 & 1 & .094 \\
N of Valid Cases & 12 & & \\
\hline
\end{tabular}

The value of Chi-Square and the $p$-value were 4.000 and 0.406 , respectively. The null hypothesis was accepted since the $p$-value $(0.406)$ was higher than $0.05(\alpha)$; there was no significant association between knowledge and performance. This fact might be due to some possible reasons.

The first reason was because of the small size of the sample. Adequate sample size is needed in research to give strength and is beneficial in terms of precise statistical tests (Creswell, 2011). It is considered that the larger the sample is, the smaller the critical value (that becomes the reference) will be.

The next reason was that the respondent with good knowledge of implicature and RT would perform well only if they had good critical thinking skills. As implicature deals with critical thinking, it would be difficult to give a good performance by merely understanding the knowledge without being critical. This critical thinking skill was called as the intervening variable.

Respondents' characteristics might also be one of the reasons of the insignificance. The characteristics of respondents such as gender, age, educational background, and others are ethical to be measured as the corresponding controls (Creswell, 2012). In this study, the respondents were heterogeneous. For the educational background, specifically, the respondents 
were from different universities for their undergraduate program which would highly be influencing. Not considering these controlling factors led to insignificant results.

The last but not least was due to the respondents' attitude in filling out the questionnaire and completing the exercises. It is highly possible for the respondents to randomly answer the questions both in the questionnaire and in the exercises without any considerations. As a result, the real depiction of both their knowledge and their performance was not shown. Then insignificant results might likely be obtained.

It is implied, moreover, that knowledge gave no contribution to performance. There might be other factors that contribute to performance. The first factor was a good comprehension of the context. As the context is very important in this case, so they have to be able to relate the context to the utterance in the dialogue containing implicatures. Another reason was owing to the respondents' lexical resources. Those who had a large number of lexical resources would find it more convenient to comprehend the context. The last factor likely to cause this to happen was the culture. British and Asians are similar in terms of their indirect communication. The respondents found it easier to agree with the characters that employed the implicature as they could relate to the situation.

\section{CONCLUSION}

In can be concluded that a lot of implicatures were found in Jane Austen's Pride and Prejudice showing that most of the characters of the novel tend to speak implicitly rather than frankly and the three goals of employing them were to make the conversation livelier and more interesting, to show politeness, and to express sarcasm. Then, the use of implicatures themselves might be because of several factors such as culture, gender, age, social classes, personality, and also ethnicity. In terms of education, the teaching of implicature must be very beneficial for qualified outcomes of $21^{\text {st- }}$ century learning. The implementation of it, moreover, would be one of the efforts in creating critical students to compete in global competition. From the dissemination, it was found that there was no significant association between knowledge and performance which showed that there might be other factors contributing to the performance.

\section{BIBLIOGRAPHY}

Abdelhafez, A. M. M. (2016). The effect of conversational implicature instruction on developing TEFL students' pragmatic competence and language proficiency. US-China Education Review A, 6(8). https://doi.org/https://doi.org/10.17265/2161$623 \mathrm{x} / 2016.08 .001$ 
Arbain, \& Sandi, M. T. A. (2016). Critical discourse analysis of Eminem's "Love the Way You Lie part II." Script Journal: Journal of Linguistic and English Teaching, 1(1).

Chemezov, Y. R., \& Gural, S. K. (2015). Difficulties in Interpretation of Situation-bound Utterances by Russian EFL Students. Procedia - Social and Behavioral Sciences, 200, 174-178. https://doi.org/https://doi.org/10.1016/j.sbspro.2015.08.042

Creswell, J. W. (2011). Educational Research: Planning, Conducting, and Evaluating Quantitative and Qualitative Research (4th ed.). Boston: Pearson Education, Inc.

Depdikbud. (2013). Permendikbud No. 81A Tentang Implementasi Kurikulum Pedoman Umum Pembelajaran.

Dinges, A. (2015). Innocent implicatures. Journal of Pragmatics, 87, 54-63. https://doi.org/https://doi.org/10.1016/j.pragma.2015.07.006

Ditjen Sumber Daya Iptek Dikti. (2018). Formula 4C untuk Bertahan pada Era Revolusi Industri 4.0.

EF EPI. (2017). EF English proficiency index 2018: The world's largest ranking of English skills.

Evason, N. (2019). British culture.

Geometry, R., \& Analysis, G. (n.d.). No 主钼的健康感を中心とした在宅高齢者における 健康関連指標に関寸る共分散構造分析Title.

Grice, P. (1975). Logic and Conversation. Syntax and Semantics: Speech Acts, 3, 41-58. https://doi.org/10.1093/alcalc/agw081

Grundy, P. (2008). Doing pragmatics (3rd ed.). Malta, IT: Hodder Education.

Guerrero, B. M. (2016). Interpreting silence on interaction. Pragmatic, cognitive and dynamic principles . Pragmalinguistica, 24, 169-186.

Holmes, J. (2007). An Introduction to Sociolinguistics (2nd ed.). London, UK: Longman.

Holtgraves, T., \& Kraus, B. (2018). Processing scalar implicatures in conversational contexts: An ERP study. Journal of Neurolinguistics, 46, 93-108. https://doi.org/https://doi.org/10.1016/j.jneuroling.2017.12.008

Indonesia. (2012). Peraturan Presiden Nomor 8 Tahun 2012 tentang Kerangka Kualifikasi Nasional Indonesia. Jakarta: Sekretariat Negara.

Ispriyani, N. (2008). Social problems and moral values in Jane Austen's Pride and Prejudice. Universitas Islam Negeri Maulana Malik Ibrahim.

Kleinke, S. (2010). Speaker activity and Grice's maxims of conversation at the interface of Pragmatics and Cognitive Linguistics. Journal of Pragmatics, 42(12), 3345-3366. https://doi.org/https://doi.org/10.1016/j.pragma.2010.05.008

Mazzone, M. (2013). Attention to the speaker. The conscious assessment of utterance interpretations in working memory. Language \& Communication, 33(2), 106-114. https://doi.org/https://doi.org/10.1016/j.langcom.2013.01.001

Mitchell, P., Robinson, E. J., \& Thompson, D. E. (1999). Children's understanding that utterances emanate from minds: using speaker belief to aid interpretation. Cognition, 72(1), 45-66. https://doi.org/https://doi.org/10.1016/S0010-0277(99)00030-X

Nanda, S., Sukyadi, D., \& Ihrom, S. M. (2012). Conversational Implicature of the Presenters in Take Me Out Indonesia. Indonesian Journal of Applied Linguistics, 1(2), 120. https://doi.org/10.17509/ijal.v1i2.89

Ngenget, S. (2017). A Revisit of the Gricean maxims in Manado Malay language. Script Journal: Journal of Linguistic and English Teaching, 2(2), 204-211. 
Nunan, D. (2003). The Impact of English as a Global Language on Educational Policies and Practices in the Asia-Pacific Region. TESOL Quarterly, 37(4), 589. https://doi.org/10.2307/3588214

OECD. (2016). PISA 2015 Results (Volume I): Excellence and Equity in Education. OECD ILibrary, 1. https://doi.org/https://doi.org/10.1787/9789264266490-en

Paltridge, B. (2012). Discourse Analysis An Introduction 2nd edition. London, UK: Continuum International Publishing Group.

Rachman, D., Nur, D. R., Sunarti, \& Puspita, R. H. (2019). The hurdles of the teacher in the practice of target language in the Indonesian EFL junior high school. Acitya Journal of Teaching and Education, 1(1), 49-54.

Sartini, S. (2014). Students' use of conversational implicature in conversational implicature in academic reading class of Ahmad Dahlan university academic year 2013/2014. The 3rd UAD TEFL International Conference 2014, 1069-1075.

Scott, C. L. (2015). What Kind of Learning for The 21 st Century? Education Research and Foresight UNESCO, 1-14.

Sperber, D., \& Wilson, D. (1986). Relevance: Communication and Cognition (2nd ed.). Oxford, UK: Blackwell Publishers Ltd.

Syrett, K., Austin, J., Sanchez, L., Germak, C., Lingwall, A., Perez-Cortes, S., ... Baker, H. (2017). The influence of conversational context and the developing lexicon on the calculation of scalar implicatures: Insights from Spanish-English bilingual children. Linguistic Approaches to Bilingualism, 7(2), 230-264. https://doi.org/10.1075/lab.14019.syr

Tan, B. P., Mahadir Naidu, N. B., \& Jamil@Osman, Z. (2018). Moral values and good citizens in a multi-ethnic society: A content analysis of moral education textbooks in Malaysia. The Journal of Social Studies Research, 42(2), 119-134. https://doi.org/https://doi.org/10.1016/j.jssr.2017.05.004

Tannen, D. (1990). You just don't understand: Women and men in conversation. New York: William Morrow \& Co.

Thomas, J. (1995). Meaning in interaction: An introduction to pragmatics. Abingdon, UK: Routledge.

Thornberg, R., \& Oğuz, E. (2016). Moral and citizenship educational goals in values education: A cross-cultural study of Swedish and Turkish student teachers' preferences. Teaching and Teacher Education, 55, 110-121. https://doi.org/https://doi.org/10.1016/j.tate.2016.01.002

Trudgill, P. (2000). Sociolinguistics: An Introduction to Language and Society. Penguin Books, 243. https://doi.org/10.2307/326846

Vergis, N. (2017). The interaction of the Maxim of Quality and face concerns: An experimental approach using the vignette technique. Journal of Pragmatics, 118, 3850. https://doi.org/https://doi.org/10.1016/j.pragma.2017.07.009 